\title{
Cation Ordering and Superstructures in Natural Layered Double Hydroxides
}

\author{
Sergey V. Krivovichev ${ }^{* a b}$, Victor N. Yakovenchuk ${ }^{b}$, Andrey A. Zolotarev, Jr. ${ }^{a}$, Gregory N. Ivanyuk ${ }^{b}$, \\ and Yakov A. Pakhomovsky
}

\begin{abstract}
Layered double hydroxides (LDHs) constitute an important group of materials with many applications ranging from catalysis and absorption to carriers for drug delivery, DNA intercalation and carbon dioxide sequestration. The structures of LDHs are based upon double brucite-like hydroxide layers $\left[\mathrm{M}^{2+}{ }_{n} \mathrm{M}^{3+}{ }_{\mathrm{m}}(\mathrm{OH})_{2(\mathrm{~m}+\mathrm{n})}\right]^{\mathrm{m}+}$, where $\mathrm{M}^{2+}=\mathrm{Mg}^{2+}, \mathrm{Fe}^{2+}, \mathrm{Mn}^{2+}, \mathrm{Zn}^{2+}$, etc.; $\mathrm{M}^{3+}=\mathrm{Al}^{3+}, \mathrm{Fe}^{3+}, \mathrm{Cr}^{3+}, \mathrm{Mn}^{3+}$, etc. Structural features of $\mathrm{LDH}$ s such as cation ordering, charge distribution and polytypism have an immediate influence upon their properties. However, all the structural studies on synthetic LDHs deal with powder samples that prevent elucidation of such fine details of structure architecture as formation of superstructures due to cation ordering. In contrast to synthetic materials, natural LDHs are known to form single crystals accessible to single-crystal X-ray diffraction analysis, which provides a unique possibility to investigate $3 \mathrm{D}$ cation ordering in LDHs that results in formation of complex superstructures, where 2D cation order is combined with a specific order of layer stacking (polytypism). Therefore $\mathrm{LDH}$ minerals provide an indispensable source of structural information for modeling of structures and processes happening in LDHs at the molecular and nanoscale levels.
\end{abstract}

Keywords: Cation ordering · Layered double hydroxides · Minerals · Superstructure

\section{Introduction}

Layered double hydroxides (LDHs) constitute an important group of materials with many applications ranging from catalysis and absorption to carriers for drug delivery, DNA intercalation and carbon dioxide sequestration. ${ }^{[1]}$ The structures of LDHs are based upon double brucite-like hydroxide layers $\left[\mathrm{M}^{2+} \mathrm{M}^{3+}(\mathrm{OH})_{2(\mathrm{~m}+\mathrm{n})}\right]^{\mathrm{m}+}$, where $\mathrm{M}^{2+}$ $=\mathrm{Mg}^{2+}, \mathrm{Fe}^{2+}, \mathrm{Mn}^{\mathrm{m}}, \mathrm{Zn}^{2+}$, etc $; \mathrm{M}^{3+}=\mathrm{Al}^{3+}$, $\mathrm{Fe}^{3+}, \mathrm{Cr}^{3+}, \mathrm{Mn}^{3+}$, etc. The positive charge of the layer is compensated by interlayer species that may consist of anions $\left(\mathrm{CO}_{3}^{2-}\right.$, $\mathrm{Cl}^{-}, \mathrm{SO}_{4}{ }^{2-}$, etc.) or both anions and cations $\left(\mathrm{Na}^{+}, \mathrm{Ca}^{2+}, \mathrm{Sr}^{2+}\right.$, etc. $)$. Structural features of LDHs such as cation ordering, charge distribution and polytypism have an immediate influence upon their properties and have been under extensive experimental

\footnotetext{
Tel.: +7 8123506688

Fax: +78123284418

E-mail: skrivovi@mail.ru

aSt. Petersburg State University

Department of Crystallography

University Emb. 7/9

199034 St. Petersburg, Russia

${ }^{b}$ Nanomaterials Research Center

Kola Science Center

Russian Academy of Sciences

Fersman Str. 14

184209 Apatity, Russia
}

${ }^{*}$ Correspondence: Prof. Dr. S.V. Krivovichevab and theoretical investigations recently. ${ }^{[2]}$ In particular, $\mathrm{Mg}$-Al cation order is important for catalytic activity of MgAl LDHs correlated with the numbers of $\mathrm{Al}^{3+}$ sites at the closest distance from an $\mathrm{Al}^{3+}$ site. ${ }^{[3]}$ Different distribution of $\mathrm{Al}$ in a $\mathrm{Mg}$ hydroxide matrix also results in different charge distribution in the interlayer, which is critically important for intercalation reactions. ${ }^{[4]}$ However, all the structural studies on synthetic LDHs deal with powder samples that prevent elucidation of such fine details of structure architecture as formation of superstructures due to cation ordering. For instance, one of the most widely studied LDHs $-\mathrm{Mg}_{2} \mathrm{Al}-\mathrm{CO}_{3}$ hydrotalcites do not reveal any signs of superstructures in their powder X-ray diffraction patterns, though short-range $\mathrm{Mg}$ - $\mathrm{Al}$ ordering has been detected by infrared (IR) and nuclear magnetic resonance (NMR) spectroscopic methods $^{[4,5]}$ as well as atomic-force microscopy (AFM) studies of surfaces of $\mathrm{Mg}_{3} \mathrm{Al}$ hydrotalcite crystals. ${ }^{[6]}$

In contrast to synthetic materials, natural LDHs are known to form single crystals accessible to single-crystal X-ray diffraction analysis, which allowed the identification of basic features of their crystal chemistry ${ }^{[7-13]}$ and to demonstrate peculiarities of cation and anion ordering. ${ }^{[14-16]}$ Fig. 1 shows crystals of quintinite $\left(\mathrm{Mg}_{2} \mathrm{Al}-\mathrm{CO}_{3}\right.$ LDHs) varieties from Kovdor alkaline massifs, Kola peninsula, Russia.[17] In this mineral deposit, LDH-group minerals form at the late stages of hydrothermal activity as a result of secondary interactions of spinel crystals (see below).
In general, there are about 40 mineral species that belong to the group of LDHs, and many of them are important from both geochemical and environmental viewpoints. Green-blue iron LDH compounds known as 'green rust' are observed as corrosion products of steel, ${ }^{[18]}$ as constituents of waste sludges ${ }^{[19]}$ and as soil minerals. ${ }^{[20]}$ Hydrotalcite-type LDHs have also been proposed as possible prebiotic information storage and transfer compounds. ${ }^{[21]}$

In this contribution, we summarize results of studies on cation ordering and superstructures in natural LDHs with special emphasis on both 2D (intralayer) and 3D (interlayer) ordering patterns and their relation to polytypic variations observed in this family of natural and synthetic compounds.

\section{Cation Ordering: 2D Superstructures}

In most of the known LDH minerals, the $\mathrm{M}^{2+}: \mathrm{M}^{3+}$ ratio in the double hydroxide layers demonstrates a strong tendency either to $2: 1$ or $3: 1$, which can be interpreted as a result of formation of ordered $\mathrm{M}^{2+}-\mathrm{M}^{3+}$ 2D superstructures shown in Fig. 2b and c. The only known exception is wermlandite, $\quad\left[\mathrm{Mg}_{7}\left(\mathrm{Al}, \mathrm{Fe}^{3+}\right)_{2}(\mathrm{OH})_{18}\right][(\mathrm{Ca}, \mathrm{Mg})$ $\left.\left(\mathrm{SO}_{4}\right)_{2}\left(\mathrm{H}_{2} \mathrm{O}\right)_{12}\right],[12]$ a mineral with the $\mathrm{M}^{2+}: \mathrm{M}^{3+}$ ratio of $7: 2$, which also shows ordered intralayer cation superstructure (Fig. $2 d)$.

In minerals with $\mathrm{M}^{2+}: \mathrm{M}^{3+}=2: 1$, the $\mathrm{M}^{2+}-$ $\mathrm{M}^{3+}$ ordering was experimentally confirmed 

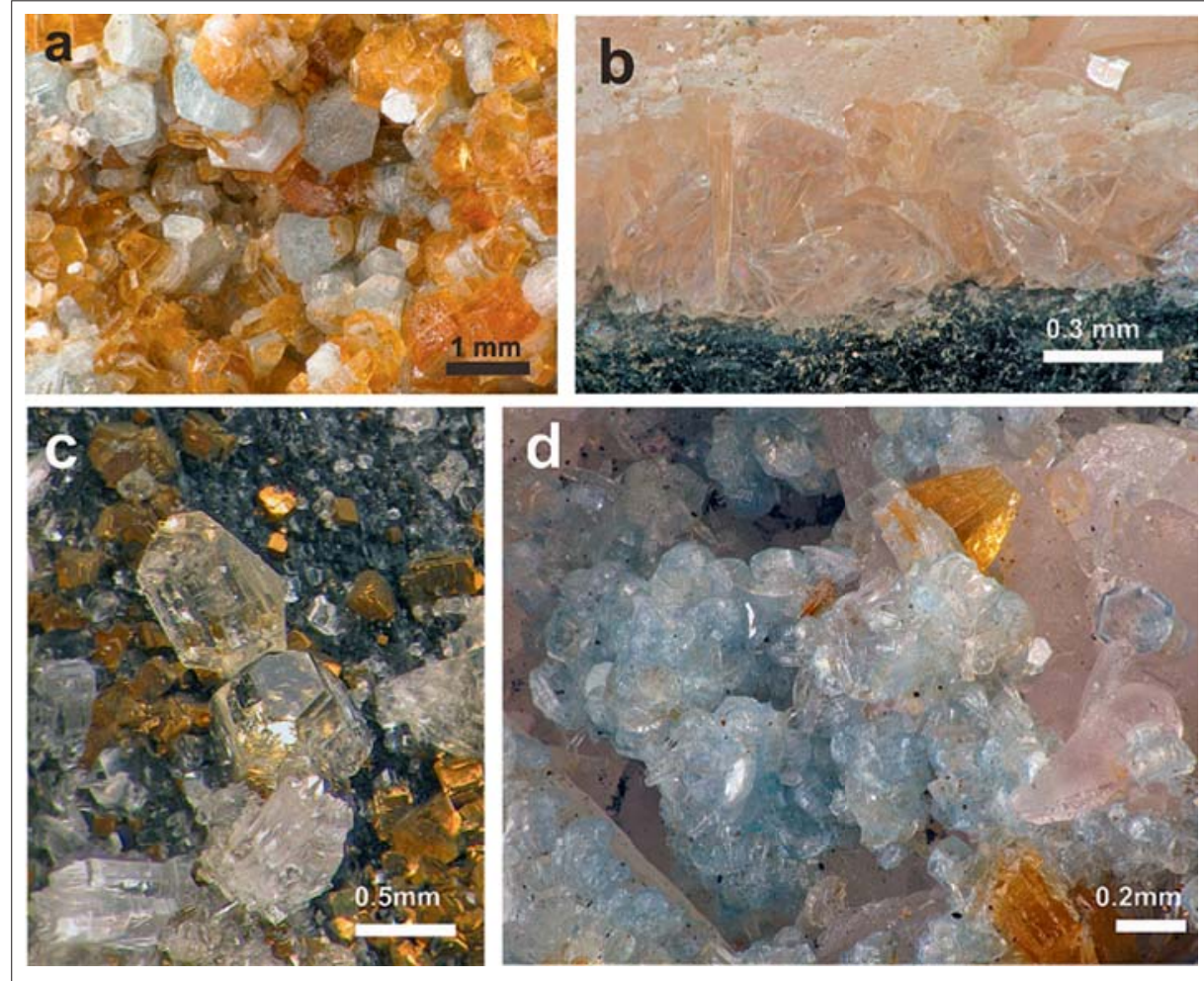

Fig. 1. Crystals of quintinite (natural $\mathrm{Mg}_{2} \mathrm{Al}-\mathrm{CO}_{3} \mathrm{LDH}$ ) polytypes from hydrothermal veins of the Kovdor alkaline massif, Kola peninsula, Russia: (a) quintinite-2H-3c, (b) quintinite-1M, (c, d) quintinite- $2 \mathrm{H}-1 \mathrm{c}$.

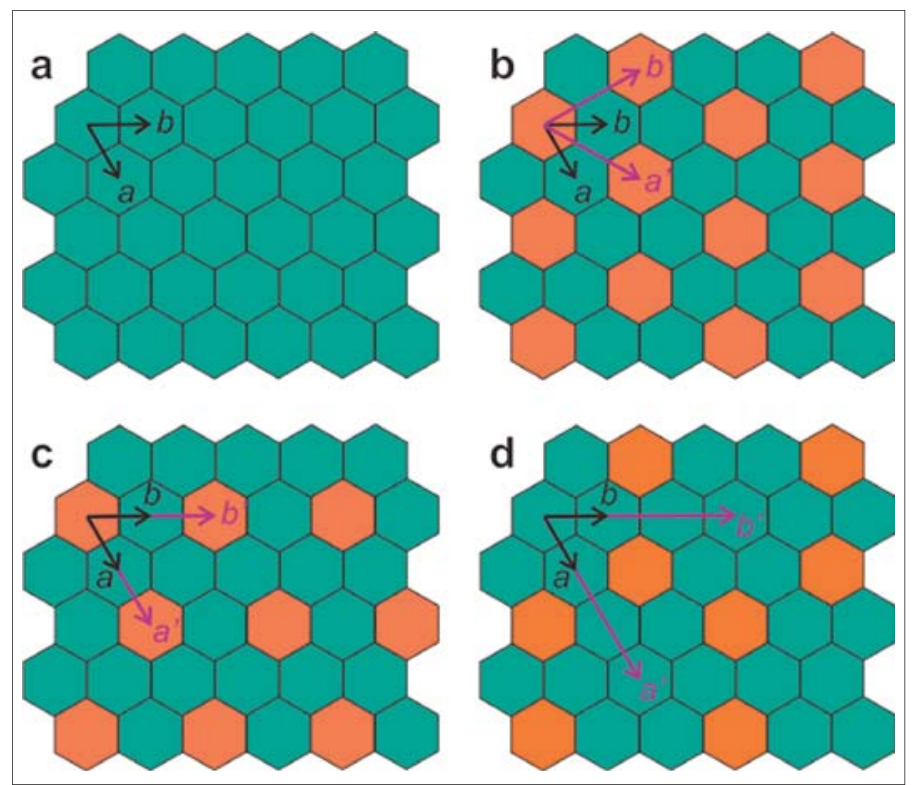

Fig. 2. $2 \mathrm{D} \mathrm{M}^{2+}-\mathrm{M}^{3+}$ cation superstructures in natural $\mathrm{LDHs}\left(\mathrm{M}^{2+}\right.$ and $\mathrm{M}^{3+}$ sites are shown as green and orange hexagons, respectively): (a) ideal brucite-like layer; (b) layer with $\mathrm{M}^{2+}: \mathrm{M}^{3+}$ $=2: 1$; (c) layer with $\mathrm{M}^{2+}: \mathrm{M}^{3+}=3: 1 ;$ (d) layer with $\mathrm{M}^{2+}: \mathrm{M}^{3+}=7: 2$.

in sulfates: motukoreaite, $\left[\mathrm{Mg}_{6} \mathrm{Al}_{3}(\mathrm{OH})_{18}\right.$ $\left[\mathrm{Na}\left(\mathrm{SO}_{4}\right)_{2}\left(\mathrm{H}_{2} \mathrm{O}\right)_{12}\right],{ }^{[22]}$ shigaite, $\left[\mathrm{Mn}^{2+}{ }_{6} \mathrm{Al}_{3}\right.$ $\left.(\mathrm{OH})_{18}\right]\left[\mathrm{Na}\left(\mathrm{SO}_{4}\right)_{2}\left(\mathrm{H}_{2} \mathrm{O}\right)_{12}\right],{ }^{[15]}$ and $\left[\mathrm{Fe}^{2+}{ }_{6} \mathrm{Al}_{3}^{3}\right.$ $\left.(\mathrm{OH})_{18}\right]\left[\mathrm{Na}\left(\mathrm{SO}_{4}\right)_{2}\left(\mathrm{H}_{2} \mathrm{O}\right)_{12}\right] ;[16] \quad \mathrm{Sb}(\mathrm{OH})_{6}-$ intercalated LDH: zincalstibite, $\left[\mathrm{Zn}_{2} \mathrm{Al}\right.$ $\left.(\mathrm{OH})_{6}\right]\left[\mathrm{Sb}(\mathrm{OH})_{6}\right]$, and cualstibite, $\left[\mathrm{Zn}_{2} \mathrm{Al}\right.$ $\left.(\mathrm{OH})_{6}\right]\left[\mathrm{Sb}(\mathrm{OH})_{6}\right] .{ }^{[23]}$ The only reports of natural $\mathrm{LDH}$ carbonates with confirmed $\mathrm{M}^{2+}-\mathrm{M}^{3+}$ order are the structures of quintinite- $2 H-1 c{ }^{[14]}$ quintinite- $2 H-3 c^{[24]}$ and quintinite-1M.[25] For zaccagnaite, $\left[\mathrm{Zn}_{4} \mathrm{Al}_{2}(\mathrm{OH})_{12}\right]\left(\mathrm{CO}_{3}\right)\left(\mathrm{H}_{2} \mathrm{O}\right)_{3}$, Merlino and Orlandi ${ }^{[26]}$ reported a perfect two-dimen-

the ordering in subsequent layers.
They studied both fresh and aged (for $24 \mathrm{~h}$ ) LDHs and found out that the aged $\mathrm{Mg}_{2} \mathrm{Al}$ specimen shows a sharp $447 \mathrm{~cm}^{-1}$ band, which is diagnostic of lattice ordering and which is absent in the IR spectra of fresh $\mathrm{Mg}_{2} \mathrm{Al}$ and both fresh and aged $\mathrm{Mg}_{3} \mathrm{Al}$ samples. On this basis, they concluded that a disorderly as-formed $\mathrm{Mg}_{2} \mathrm{Al}$ material through a solution-precipitation process transforms into material with regular $\mathrm{Mg}-$ $\mathrm{Al}$ order. The driving force for the ordering is to avoid direct contacts of $\mathrm{Al}(\mathrm{OH})_{6}$ octahedra, which, in $\mathrm{Mg}_{2} \mathrm{Al} \mathrm{LDHs}$, is possible only through formation of a regular honeycomb superstructure. In contrast, in $\mathrm{Mg}_{3} \mathrm{Al}$ LDHs, Al-Al avoidance may be achieved in a disordered fashion, i.e. without formation of a periodic superstructure.

Sideris et al..$^{4]}$ investigated $\mathrm{Mg}-\mathrm{Al}$ ordering in $\mathrm{Mg}-\mathrm{Al}$ carbonate $\mathrm{LDH}$ with the $\mathrm{Mg}: \mathrm{Al}$ ratio of $c a .5: 1,4: 1$ and $2: 1$ by means of combined ${ }^{1} \mathrm{H}$ magic angle spinning and ${ }^{25} \mathrm{Mg}$ triple-quantum magic angle spinning nuclear magnetic resonance (NMR) spectroscopy and found that the $\mathrm{Mg}^{2+}$ and $\mathrm{Al}^{3+}$ are not randomly distributed in the metal hydroxide sheets and that in $\mathrm{Mg}_{2} \mathrm{Al} \mathrm{LDH}$ they are ordered in a honeycomb arrangement.

To our knowledge, the only evidence of formation of $2 \mathrm{D}$ cation superstructures in LDHs with $\mathrm{M}^{2+}: \mathrm{M}^{3+}=3: 1$ comes from nanoscale imaging of surfaces of hydrotalcite crystals with the ordering pattern shown in Fig. 2c. It is worthy to note that, though other superstructures can also be theoretically constructed, the one shown in Fig. 2c has the most uniform distribution of trivalent cations over octahedral layer.

When compared to the monocation $\left[\mathrm{M}(\mathrm{OH})_{2}\right]$ octahedral layer (Fig. 2a), cation ordering results in formation of $2 \mathrm{D}$ supercells related to the $a_{\mathrm{br}}$ parameter $(\sim 3.1-3.2$ $\AA$ ) of the brucite-like layer as follows:

(i) for the hexagonal layer with $\mathrm{M}^{2+}: \mathrm{M}^{3+}=$ $2: 1$ (Fig. 2b): $a^{\prime}=b^{\prime}=3^{1 / 2} a_{\mathrm{br}}(\sim 5.2-5.4$ A);

(ii) for the hexagonal layer with $\mathrm{M}^{2+}: \mathrm{M}^{3+}=$ 2:1 (Fig. 2c): $a^{\prime}=b^{\prime}=2 a_{\mathrm{br}}(\sim 6.3-6.4$ A);

(iii) for the hexagonal layer with $\mathrm{M}^{2+}: \mathrm{M}^{3+}=$ 7:2 (Fig. 2d): $a^{\prime}=b^{\prime}=3 a_{\mathrm{br}}(\sim 9.3 \AA)$.

The 2D supercells listed above can be observed by X-ray diffraction methods only when the cation ordering propagates in the third dimension. The resulting symmetry of the whole structure is controlled by the order and pecularities of the layer stacking.

Detection of the cation ordering is especially problematic in synthetic powder samples and, in particular, in synthetic quintinites ( $\left.\mathrm{Mg}_{2} \mathrm{Al}-\mathrm{CO}_{3} \mathrm{LDHs}\right)$. Richardson and Braterman ${ }^{[5]}$ investigated shortrange order in $\mathrm{Mg}-\mathrm{Al} \mathrm{LDHs}$ with $\mathrm{Mg}: \mathrm{Al}$ $=2: 1$ and $3: 1$ by infrared (IR) spectroscopy in the region between 400 and $250 \mathrm{~cm}^{-1}$.

\section{LDH Polytype Nomenclature}

In the plane perpendicular to the direction of layer stacking, cations and anions may occupy three distinct sites: A, B and C (similar to the sites of spheres in closest 


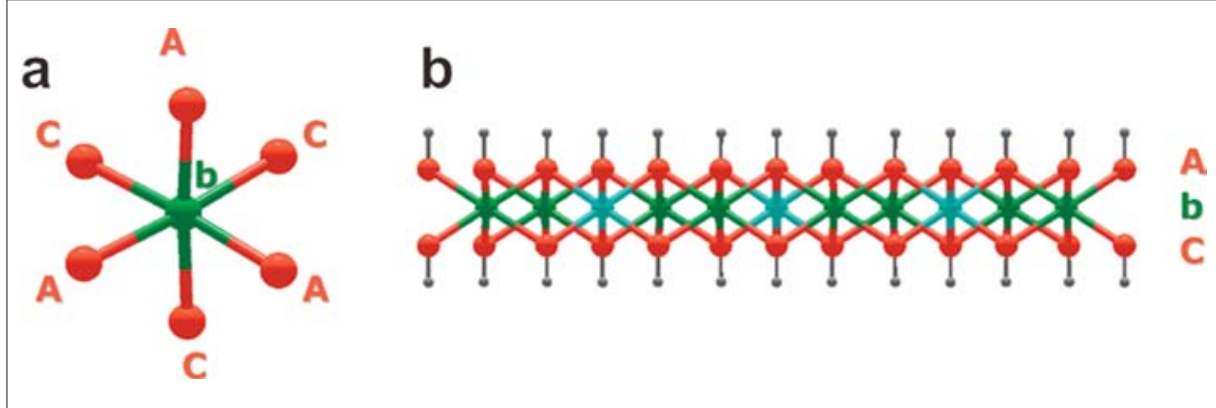

Fig. 3. Projection of metal-centered octahedron with identification of cation position as $\mathbf{b}$ and anion positions as $\mathbf{A}$ and $\mathbf{C}$ (a) and projection of double hydroxide layer parallel to its extension (b).

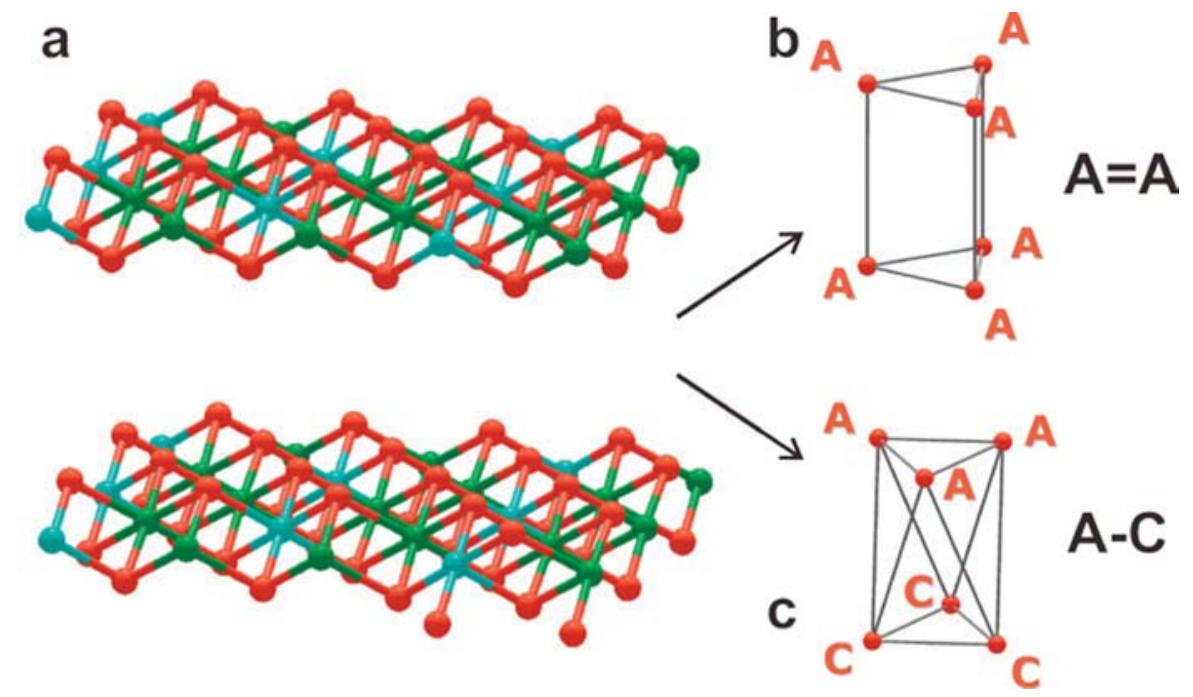

Fig. 4. The interlayer space in the structures of LDHs (a) may consist either from trigonal prisms (b: P-type interlayer) or octahedra (c: O-type interlayer).

packings). The upper (A, B, C) and lower $(\mathbf{a}, \mathbf{b}, \mathbf{c})$ case symbols are reserved for positions of hydroxyls and cations, respectively. For instance, if hydroxyl anions of the layer are in the $\mathbf{A}$ and $\mathbf{C}$ sites, the cations occupy the $\mathbf{b}$ sites, and the layer has a structural formula AbC (Fig. 3). Since positions of the cations within the layer are uniquely determined by the hydroxyl positions, they can be omitted.

Stacking of two layers may result in formation of two different types of interlayers (Fig. 4). In the case where the upper hydroxide sheet of the lower layer and the lower hydroxide sheet of the upper layer have the same notations (e.g. A and $\mathbf{A})$, the interlayer may be represented as consisting of trigonal prisms (Fig. 4b). This type of interlayer is referred to as a P-type and denoted with an equal sign (=) (e.g. ....A=A...). In the case where the upper hydroxide sheet of the lower layer and the lower hydroxide sheet of the upper layer have different notations (e.g. A and B), the interlayer may be represented as consisting of elongated octahedra (Fig. 4c). This type of interlayer is referred to as an O-type and denoted with a dash (-) (e.g. ....A-B...). Using this simple and elegant scheme of notations, Bookin and Drits ${ }^{[27]}$ derived all two- and three-layer LDH polytypes and six-layer rhombohedral polytypes and calculated their powder X-ray diffraction patterns. For instance, there are exactly three two-layer polytypes, ...AC $=\mathbf{C A}=\mathbf{A C}$..., ...AC-AB-AC ..., and ...AC-BA=AC ..., denoted as $2 \mathrm{H}_{1}, 2 \mathrm{H}_{2}$, and $2 \mathrm{H}_{3}$, respectively. Out of these three polytypes, $2 H_{1}$ polytype appears to be the most common in minerals (it is obviously the one observed for manasseite). In this polytype, all cations occupy the b sites and all interlayers are of the P-type. Among three-layer polytypes, the most common is the $3 R_{1}$ polytype that has the structure ...AC $=\mathbf{C B}=\mathbf{B} \mathbf{A}=\mathbf{A C} \ldots$, i.e. all its interlayers are of the P-type. On the basis of the nomenclature proposed by Bookin and Drits, ${ }^{[27]}$ Bookin et al. ${ }^{[28]}$ investigated experimentally studied natural LDHs and reported the occurrence of twoand three-layer polytypes $2 H_{1}$ and $3 R_{1}$ in $\mathrm{CO}_{3}$-bearing minerals. In contrast, in sul- fate-bearing LDHs, the situation is more complex: both one- and three-layer polytypes are observed with both $\mathrm{P}$ - and O-type interlayers. However, despite the exhaustive and rigorous character in derivation of the polytypes, the current nomenclature does not take into account such important structural feature of LDHs as the ordering of $\mathrm{M}^{2+}$ and $\mathrm{M}^{3+}$ cations within the double hydroxide layers.

\section{Cation Superstructures in Natural LDHs: Case Studies}

Recently, Krivovichev et al. ${ }^{[24,25]}$ reported structures of natural LDH crystals, polytypes of quintinite, ${ }^{[29]}$ from two different samples from hydrothermal veins of Kovdor alkaline massif, Kola peninsula, Russia (Fig. 1a, b). Chemical composition of the samples studied by the wavelength dispersion spectrometry using a Cameca MS-46 electron microprobe and infrared spectroscopy provided the same (within standard errors) chemical formula, $\left[\mathrm{Mg}_{4} \mathrm{Al}_{2}(\mathrm{OH})_{12}\right]\left(\mathrm{CO}_{3}\right)\left(\mathrm{H}_{2} \mathrm{O}\right)_{3}$. Single-crystal X-ray diffraction study revealed that the diffraction pattern of the samples quintinite- $2 H-3 c$ and quintinite- $1 M$ was characterized by the presence of strong and sharp Bragg reflections and weakly discrete diffuse-like lines. Whereas sharp Bragg reflections originate from basic layer stacking of metal hydroxide layers, weak reflections are indicative of formation of 3-D cation superlattices due to the $\mathrm{Mg}-\mathrm{Al}$ ordering. For instance, diffuse streaks in the diffraction pattern of quintinite- $2 H-3 c$ are extended along $\mathbf{c}^{*}$ and centered at $h-k \neq$ $3 n$ relative to a supercell indexing ( $R$-cell, $a=5.2745(7), c=45.36(1) \AA)$. Indexing of sharp Bragg reflections only resulted in a small subcell with parameters $a=3.045$, $c=15.12 \AA$, which are approximately in agreement with unit-cell parameters of the $2 \mathrm{H}_{1}$ polytype of $\mathrm{Mg}-\mathrm{Al} \mathrm{LDHs}{ }^{[14]}$ In the large supercell, indices of the sharp Bragg reflections correspond to conditions $h-k=$ $3 n$ and $l=3 n$ (Fig. 5a, b). A similar situation is observed also for quintinite- $1 M$.

The unit-cell parameters obtained for the two samples are given in Table 1 . It is noteworthy that, in quintinite- $2 \mathrm{H}-3 \mathrm{c}, \mathrm{Mg}-$ $\mathrm{Al}$ ordering results in formation of a threefold superstructure relative to the usual hexagonal $2 \mathrm{H}$ polytype, whereas, in quintinite- $1 M$, cation ordering and superlattice formation results in a dramatic reduction of symmetry: from rhombohedral (as in $3 R$ polytype) to monoclinic (and thus the sample should be qualified as a $1 M$ polytype).

The structures of all four crystals consists of metal hydroxide layers, $\left[\mathrm{Mg}_{2} \mathrm{Al}(\mathrm{OH})_{6}\right]^{+}$, and a disordered interlayer (Fig. 6a). According to LDH polytype nomenclature, ${ }^{[27]}$ the layer stacking 


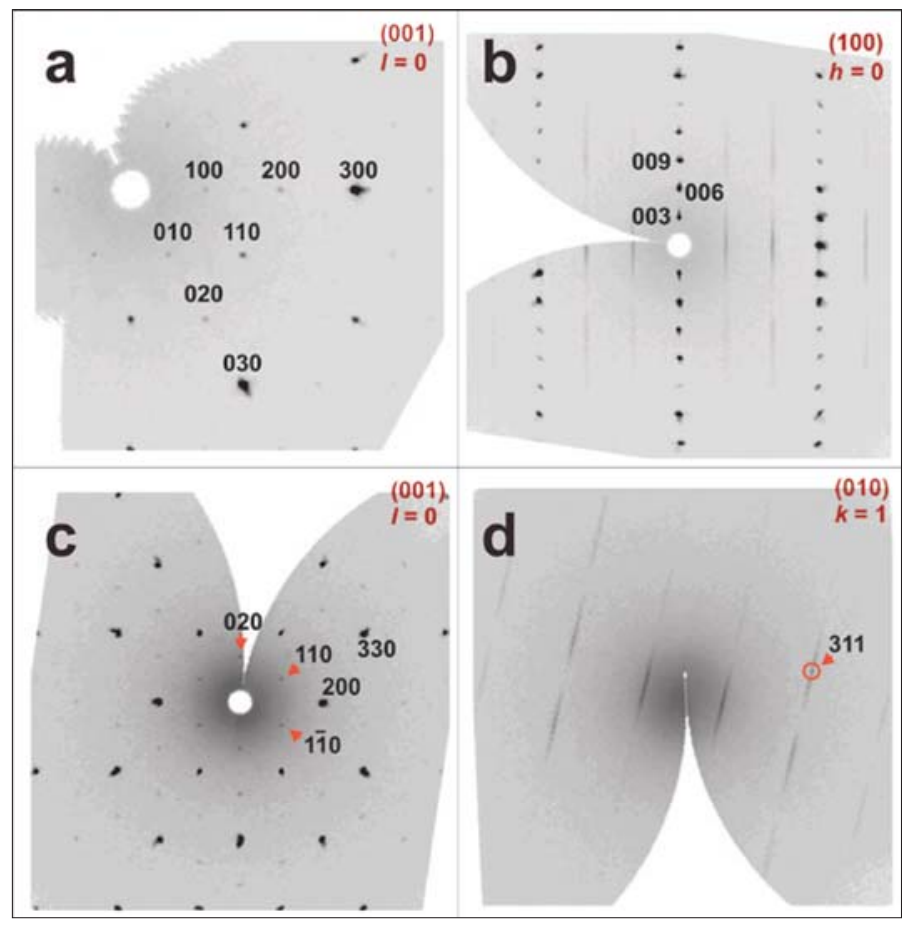

Fig. 5. Reconstructed sections of reciprocal diffraction space showing sharp and strong Bragg reflections and weak diffuse-like superstructure reflections for crystal quintinite- $2 \mathrm{H}-3 \mathrm{c}$ (a and b) and quintinite- $1 M$ (c and d). Superstructure reflections are indicated by red arrows.
Table 1. Crystallographic data for natural $\mathrm{Mg}_{2} \mathrm{Al}-\mathrm{CO}_{3} \mathrm{LDHs}$ (quintinites)

$\begin{array}{lll}\text { Sample } & \text { quintinite-2H-3c } & \text { quintinite- } 1 M \\ \begin{array}{l}\text { Sym- } \\ \text { metry }\end{array} & \text { Rhombohedral } & \text { Monoclinic } \\ \begin{array}{l}\text { Space } \\ \text { group }\end{array} & R 32 & C 2 / m \\ a[\AA] & 5.2745 & 5.2662 \\ b[\AA]] & - & 9.114 \\ c[\AA]] & 45.364 & 7.766 \\ \beta[\circ] & - & 103.17 \\ V\left[\AA^{3}\right] & 1093.0 & 362.9\end{array}$

in quintinite- $2 H-3 c$ can be described as ....AC $=\mathbf{C A}=\mathbf{A C} \ldots$, with $\mathbf{A}$ and $\mathbf{C}$ being positions of hydroxide ions and $\mathbf{b}$ position of cations (in the same manner as in closest packing of equal spheres). The sequence of layers within the unit cell can be described as $\ldots \mathbf{A C}=\mathbf{C A}=\mathbf{A C}=\mathbf{C A}=\mathbf{A C}=\mathbf{C A} \ldots$, since the unit cell contains exactly six double hydroxide layers. Thus, in terms of layer stacking sequence, the structure clearly has a pseudo-period with $c$ parameter of about $15.12 \AA$, i.e. three times smaller than the one observed experimentally. The reason for tripling the $c$ parameter is $\mathrm{Mg}-\mathrm{Al}$ ordering in the $\left[\mathrm{Mg}_{2} \mathrm{Al}(\mathrm{OH})_{6}\right]^{+}$layer. There are three symmetry-independent octahedral cation sites in the structure of quintinite$2 \mathrm{H}-3 \mathrm{c}$. Since the site-scattering factors of $\mathrm{Mg}^{2+}$ and $\mathrm{Al}^{3+}$ cations are nearly identical,

Fig. 6. Crystal structure of quintinite- $2 \mathrm{H}-3 \mathrm{c}$ (a) and stacking of $\mathrm{Mg}_{2} \mathrm{Al}$ cation arrays with the $\left[\mathrm{Mg}_{4} \mathrm{Al}_{2}\right]$ repeat sequence (b) and three different positions of the arrays (c). the only way to distinguish between $\mathrm{Mg}$ and $\mathrm{Al}$ sites is to analyse distribution of the $\mathrm{M}-\mathrm{O}$ bond lengths. The structure refinement indicates one $\mathrm{M}$ site with the $\mathrm{M}$ bond lengths in the range of 1.936-1.940 $\AA$ (assigned to $\mathrm{Al}$ ) and two $\mathrm{M}$ sites with the $\mathrm{M}-\mathrm{O}$ bond lengths of 2.042-2.045 and 2.070-2.077 $\AA$ (assigned to $\mathrm{Mg}$ ). According to Bookin and Drits' nomenclature, [27] in the $2 \mathrm{H}$ polytype, all anions are either in $\mathbf{A}$ or $\mathbf{C}$ positions, whereas all cations are in the $\mathbf{b}$ positions. However, the sequence of the $\mathbf{b}$ positions if seen along the $c$ axis is occupied by $\mathrm{Mg}$ and $\mathrm{Al}$ cations differently. This sequence can be written as $[\mathrm{MgMg}$ $\mathrm{MgMgAlAl}]$ or $\left[\mathrm{Mg}_{4} \mathrm{Al}_{2}\right]$, taking into account that the content given in the square brackets corresponds to the $c$ parameter repeat. Considering possible relative positions of the 2D Mg-Al cation array, one may distinguish exactly three different $\mathrm{Mg}_{2} \mathrm{Al}$ arrays related to each other by either $a$ or $b$ translations (Fig. 6b). These arrays may be indicated as $\mathbf{b}_{1}, \mathbf{b}_{2}$ and $\mathbf{b}_{3}$ 


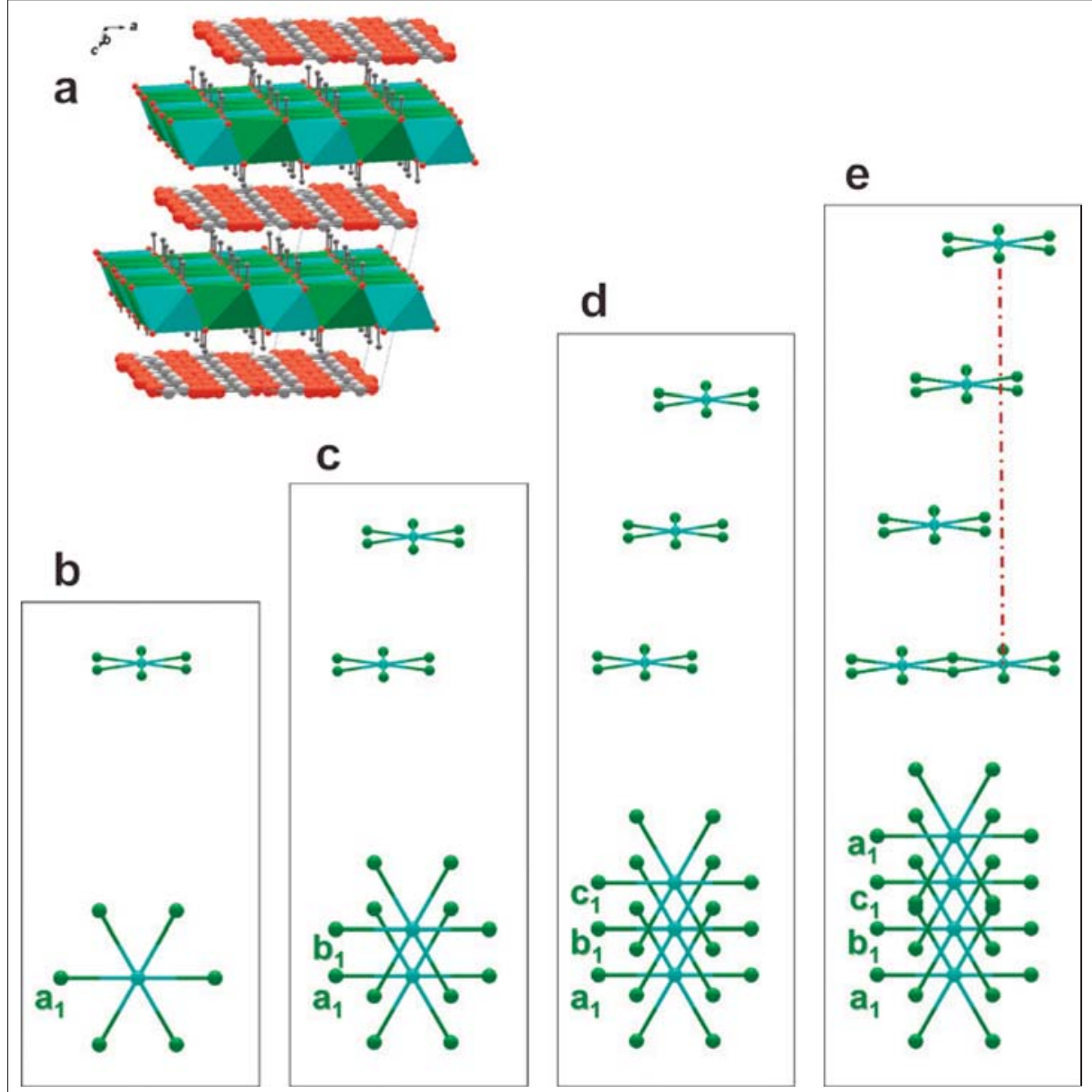

Fig. 7. Crystal structure of quintinite- $1 \mathrm{M}$ (a) and schemes of stacking of $\mathrm{Mg}_{2} \mathrm{Al}$ cation arrays along the direction perpendicular to the layers $(b-e)$.

(since all cations are in the $\mathbf{b}$ positions). Therefore the full description of the layer sequence (i.e. a description that takes into account cation ordering) can be written as $\ldots=A b_{1} C=C b_{1} A=A b_{2} C=C b_{2} A=A b_{3} C=C$ $\mathbf{b}_{3} \mathbf{A}=\ldots$

The layer stacking in quintinite$1 M$ (Fig. 7a) can be described as $\ldots=\mathbf{A B}=\mathbf{B C}=\mathbf{C A}=\ldots$, i.e. it corresponds to a rhombohedral polytype structure typical for most synthetic Mg-Al LDHs. [30] However, because of the cation ordering, the situation becomes more complex and can be deciphered from the analysis of relative position of the $2 \mathrm{D} \mathrm{Mg}_{2} \mathrm{Al}$ cation arrays (Fig. 7b-e). First, it is obvious that cations in quintinite- $1 M$ are located in all possible sites, $\mathbf{a}, \mathbf{b}$, and $\mathbf{c}$, so that the full description of the layer sequence should be written as $\ldots=\mathbf{A c B}=\mathbf{B a C}=\mathbf{C b A}=\ldots$ In the case of complete $\mathrm{Mg}-\mathrm{Al}$ disorder, a structure with this sequence would have a rhombohedral symmetry (space group $R-3 m$ ), but cation ordering results in symmetry reduction and formation of superstructure. As can be seen from Fig. 7b-d, $\mathrm{Al}$ cations in adjacent $\mathrm{Mg}_{2} \mathrm{Al}$ arrays are lo- be seen that electron density maxima corresponding to the $\mathrm{O}$ atoms of carbonate groups are associated into almost continuous toroidal regions, which makes the refinement procedure a difficult task. Since there are no indications of any dynamic disorder effects in the structure (e.g. rotation of carbonate triangles), we assume that the observed continuous character of the tori is due to positional disorder. Fig. $8 \mathrm{~b}$ shows an approximate identification of the electron density peaks as proposed by the refinement.

From the unit-cell parameters and the results of crystal-structure refinement, it is evident that quintinite- $1 M$ is isostructural to the monoclinic polytype of $\left[\mathrm{Li}_{2} \mathrm{Al}_{4}(\mathrm{OH})_{12}\right]\left(\mathrm{CO}_{3}\right)\left(\mathrm{H}_{2} \mathrm{O}\right)_{3}$ reported previously.[2f,31] However, it is the first case of detection of monoclinic symmetry in natural and synthetic LDHs with di- and trivalent cations.

\section{Conclusions}

In contrast to synthetic samples of LDHs, natural samples provide a unique possibility to investigate $3 \mathrm{D}$ cation ordering, which may result in formation of rather intricate superstructures, where 2D cation order is combined with a specific order of layer stacking. These effects may easily be neglected in powder X-ray diffraction

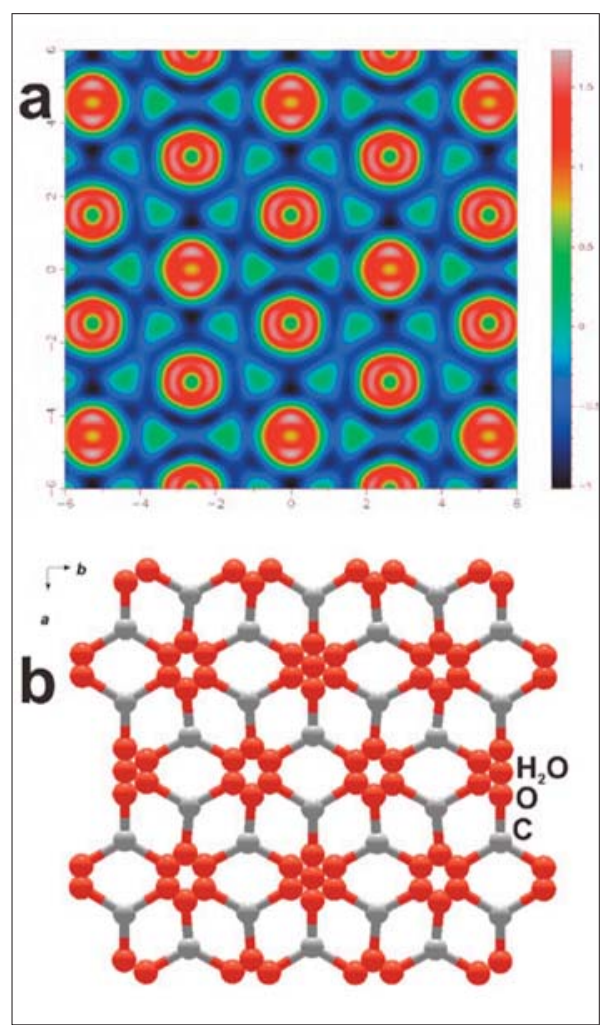

Fig. 8. Electron density Fourier map of interlayer in quintinite-1M (a) and model of disordered interlayer arrangement of carbonate anions and water molecules (b). 
studies, since superstructure reflections are too weak to be detected, especially in the case of Mg-Al LDHs with almost identical $\mathrm{Mg}$ and $\mathrm{Al}$ scattering factors. In this case, LDH minerals provide an indispensable source of structural information for modeling of structures and processes happening in LDHs at the molecular and nanometer levels.

\section{Acknowledgements}

This work was supported by the Russian Foundation for Basic Research (grant \# 1005-00431) and through a Russian Federation President grant for young candidates of sciences (to AAZ, grant \# MK-1783.2010.5).

Received: June 21, 2010

[1] a) J.-H. Choy, S.-Y. Kwak, J.-S. Park, Y.-J. Jeong, J. Portier, J. Amer. Chem. Soc. 1999. 121, 1399; b) 'Layered Double Hydroxides: Present and Future', Ed. V. Rives, Nova Science Publishers Inc., New York, 2001; c) A. I. Khan, D. O'Hare, J. Mater. Chem. 2002, 12, 3191; d) 'Layered double hydroxides', Eds. X. Duan, D. G. Evans, Structure and Bonding, Vol. 119 Springer Verlag, Berlin, 2006.

[2] a) J. Wang, A. G. Kalinichev, R. J. Kirkpatrick, X. Hou, Chem. Mater. 2001, 13, 145; b) J. Wang, A. G. Kalinichev, J. Amonette, R. J. Kirkpatrick, Amer. Mineral. 2003, 88, 398; c) P. P. Kumar, A. G. Kalinichev, R. J. Kirkpatrick, J. Phys. Chem. 2006, B110, 3841; d) J.-M.R. Génin, C. Ruby, C. Upadhyay, Solid State Sci. 2006, 8, 1330; d) M.A. Thyveetil, P. V. Coveney, H. C. Greenwell, J. L. Suter, J. Amer. Chem. Soc. 2008, 130 , 4742; e) C. Ruby, M. Abdelmoula, R. Aissa, G. Medjahdi, M. Brunelli, M. François, J. Solid State Chem. 2008, 181, 2285; f) S. Britto, P. V. Kamath, Inorg. Chem. 2009, 48, 11646; g) R. E. Johnsen, P. A. Norby, J. Phys. Chem. 2009, C113, 19061; h) B. C. Christiansen, T. BalicZunic, P. O. Petit, C. Frandsen, S. Morup, H. Geckeis, A. Katerinopoulou, S. L. S. Stipp, Geochim. Cosmochim. Acta 2009, 73, 3579.

[3] D. Kim, C. Huang, H. Lee, I. Han, S. Kang, S. Kwon, J. Lee, Y. Han, H. Kim, Appl. Cat. A: Gen. 2003, 249, 229

[4] P. J. Sideris, U. G. Nielsen, Z. H. Gan, C. P. Grey, Science 2008, 321, 113.

[5] M. C. Richardson, P. S. Braterman, J. Phys. Chem. 2007, C111, 4209.

[6] a) K. Yao, M. Taniguchi, M. Nakata, M Takahashi, A. Yamagishi, Langmuir 1998, 14,
2410; b) K. Yao, M. Taniguchi, M. Nakata, M. Takahashi, A. Yamagishi, Langmuir 1998, 14, 2410 .

[7] L. Ingram, H. F. W. Taylor, Mineral. Mag. 1967, $36,465$.

[8] R. Allmann, Acta Crystallogr. 1968, B24, 972.

[9] R. Allmann, J. D. H. Donnay, Amer. Mineral. 1969, 54, 296.

[10] R. Allmann, H. P. Jepsen, N. Jb. Mineral. Mh. 1969, 544.

[11] H. F. W. Taylor, Mineral. Mag. 1973, 39, 377.

[12] J. Rius, R. Allmann, Z. Kristallogr. 1984, 168, 133.

[13] R. S. W. Braithwaite, P. J. Dunn, R. G. Pritchard, W. H. Paar, Mineral. Mag. 1994, 58, 79.

[14] A. V. Arakcheeva, D. Yu. Pushcharovskii, D. Atencio, G. U. Lubman, Crystallogr. Rep. 1996, $41,972$.

[15] M. A. Cooper, F. C. Hawthorne, Can. Mineral. 1996, 34, 91 .

[16] D. M. C. Huminicki, F. C. Hawthorne, Can. Mineral. 2003, 41, 79 .

[17] G. Yu. Ivanyuk, V. N. Yakovenchuk, 'Minerals of the Kovdor Massif', Apatity, RAS Kola Science Center publishing, 1997.

[18] P. P. Stampfl, Corr. Sci. 1969, 9, 185.

[19] B. C. Koch, S. Morup, Clay Miner. 1991, 26, 577.

[20] F. Trolard, C. R. Geosci. 2006, 338, 1158.

[21] a) G. O. Arrhenius, Helv. Chim. Acta 2003, 86, $1569 ;$ b) H. C. Greenwell, P. V. Coveney, Orig. Life Evol. Biosph. 2006, 36, 13.

[22] J. Rius, F. Plana, N. Jb. Mineral. 1986, 6, 263.

[23] E. Bonaccorsi, S. Merlino, P. Orlandi, Amer. Mineral. 2007, 92, 198.

[24] S. V. Krivovichev, V. N. Yakovenchuk, E. S. Zhitova, A. A. Zolotarev, Ya, A. Pakhomovsky, G. Yu. Ivanyuk, Mineral. Mag. 2010, submitted.

[25] S. V. Krivovichev, V. N. Yakovenchuk, E. S. Zhitova, A. A. Zolotarev, Ya, A. Pakhomovsky, G. Yu. Ivanyuk, Mineral. Mag. 2010, submitted.

[26] S. Merlino, P. Orlandi, Amer. Mineral. 2001, 86 , 1293.

[27] A. S. Bookin, V. A. Drits, Clays Clay Miner. 1993, $41,551$.

[28] A. S. Bookin, V. I. Cherkashin, V. A. Drits, Clays Clay Miner. 1993, 41, 558.

[29] G. Y. Chao, R. A. Gault, Can. Mineral. 1997, $35,1541$.

[30] M. Bellotto, B. Rebours, O. Clause, J. Lynch, D. Bazin, E. Elkaim, J. Phys. Chem. 1996, 100, 8527.

[31] a) J. P. Thiel, C. K. Chiang, K. R. Poeppelmeier, Chem. Mater. 1993, 5, 297; b) S. Britto, G. S. Thomas, P. V. Kamath, S. Kannan, J. Phys. Chem. 2008, C112, 9510. 